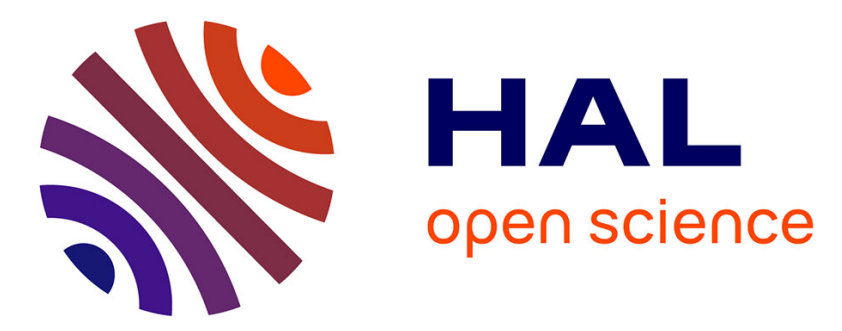

\title{
Workers' Perspective About Organizational Climate in Knowledge Management: Automotive Assembly-Line
} Case

Indira A. Rodriguez, Aline Garcia, Suelen Morais, Jorge Muniz Jr., Timothy P. Munyon

\section{To cite this version:}

Indira A. Rodriguez, Aline Garcia, Suelen Morais, Jorge Muniz Jr., Timothy P. Munyon. Workers' Perspective About Organizational Climate in Knowledge Management: Automotive Assembly-Line Case. IFIP International Conference on Advances in Production Management Systems (APMS), Sep 2016, Iguassu Falls, Brazil. pp.723-730, 10.1007/978-3-319-51133-7_85 . hal-01615804

\author{
HAL Id: hal-01615804 \\ https://hal.inria.fr/hal-01615804
}

Submitted on 12 Oct 2017

HAL is a multi-disciplinary open access archive for the deposit and dissemination of scientific research documents, whether they are published or not. The documents may come from teaching and research institutions in France or abroad, or from public or private research centers.
L'archive ouverte pluridisciplinaire HAL, est destinée au dépôt et à la diffusion de documents scientifiques de niveau recherche, publiés ou non, émanant des établissements d'enseignement et de recherche français ou étrangers, des laboratoires publics ou privés.

\section{(c)(1)}

Distributed under a Creative Commons Attribution| 4.0 International License 


\title{
Workers' Perspective About Organizational Climate in Knowledge Management: Automotive Assembly-line Case
}

\author{
Indira A. Rodriguez ${ }^{1}$, Aline Garcia ${ }^{1}$, Suelen C. F. Morais ${ }^{1}$, Jorge Muniz Jr ${ }^{1}$, \\ and Timothy P. Munyon ${ }^{2}$ \\ 1 Universidade Estadual Paulista, São Paulo, Brazil \\ indiraarias1986@gmail.com \\ 2 University of Tennessee, Knoxville, USA \\ tmunyon@utk.edu
}

\begin{abstract}
The purpose of this paper is to analyze the relation between Organizational Climate and Knowledge Management in the shop floor. The study is conducted in an auto part plant inserted in a Truck Factory with 7 partners. 44 blue collar workers were interviewed. The results show a relationship between Organizational Climate and Knowledge Management in the automotive sector, evidenced by the significant correlations between the variables analyzed. The unemployment situation can negatively influence the climate of organizations. The positive social interaction can preserve knowledge sharing even when there are weaknesses in the organizational climate. Future research can compare the results of this study with another sample in the same environment in stable employment situation. Other research may replicate this study with a larger number of participants.
\end{abstract}

Keywords: Organization climate $\cdot$ Knowledge management $\cdot$ Shop floor workers.

\section{Introduction}

This paper, analyses the relation between Organizational Climate and Knowledge Management in the industry shop floor. The Organizational Climate (OC) is the way in which members of the organization perceive or characterize their working environment [1]. OC encompasses the organizational structure and processes, interpersonal relationship, management compensation, employee behavior, performance expectations and growth opportunities. It is the result of interaction among the organizational components: structure, systems, culture, leader behavior, and the psychological needs of workers.

Organizational Climate refers to common practices, shared ideas and value systems that an organization follows [2]. For members of the organization, climate takes the form of a set of attributes and expectations that describe the general pattern of organizational activities [3] playing a key role in shaping employees, behaviors and influences their perception of Knowledge Management KM [4]. 
The study of OC is multidisciplinary and encompasses criteria that are related to the KM, but studies indicate lack of consensus on evaluating this influence $[5,6,7,8,9,10,11]$. Highlighted the importance of provoking beliefs, commitments, situations and appropriate interactions in organizations, elements connected with the OC, and to provide the information that is converted into knowledge and can move by organizations, positively influencing judgments, behaviors and attitudes [12].

The KM is the systematic, formal and deliberate acting in order to capture, preserve, share, and (re) use the tacit and explicit knowledge, created and used by persons during routine tasks and improvement of production processes in order to generate results measurable for the organization and for the people [13]. The theme relevance is related to its impact on the organization's performance improvements. KM benefits focusing on organizational problems solving, which will connect KM with the company's performance and demonstrate financial impacts and non-financial $[14,15]$.

Competitive advantage for organizations is relating the continuously innovative environment in its internal processes, procedures and resources [16]. Enterprises can encourage employees to collaboration, information exchange, open communication, and to explore non-routine alternatives through formulation of innovative climate [17]. Cooperation among individuals plays a critical role on development interesting and innovative ideas occur [3].

Research indicates the importance of creating a favorable psychological environment within the company as the facilitator of knowledge sharing in sectors as banking [9], educational, hospital [17], steel making, computer and telecommunications. The research results discussion are grouped in (a) positive impact raised by the $\mathrm{OC}$ in $\mathrm{KM}$, (b) negative impact of unfavorable OC in KM and (3) best practices of Organizational Climate to favor the Knowledge Management.

Moreover, literature analyzed shows a consensus to point out that the favorable $\mathrm{OC}$ can promote benefits of the KM as higher degree of sharing and application of knowledge through social interaction and favorable cooperation, open communication, socialization among employees, coordination behavior, increased confidence and integration with work $[6,7,8,9]$.

There is a necessity to create a OC to support organization members to develop a positive attitude towards the work, followed by subjective norms, extrinsic motivation $[9,10]$, promoting an open climate that encourages risk-taking, trust and open interaction, collecting and describing individual knowledge, intellectual capital and organizing your organization's information [11]. Innovative organizations need a OC that stimulates an open mind, committed and involved relationships of trust and mutual support [6], to develop new ideas and respond to new opportunities, must involve a cultural change, by dedicating time of transformation of knowledge into innovation activities, providing reinforced KM levels [8].

Examples are the positive impact and in turn best practices of organizational climate to favor the knowledge management, but Organizations with a lot of formalization and centralization hinder integration among members of the 
organization and social interaction which ends up promoting the organizational climate barriers that compromise the good performance of knowledge management levels [5].

New information technologies and innovation also have a cause-effect relationship between organizational climate and knowledge management. The use of information can help the application of knowledge management technology, so it should prevail a grip of climate to the system, which must be practical and dynamic, otherwise the positive impact can be reversed and seen as an obstacle in organizations [5].

\section{Method}

The research is a quali-quanti study conducted in one assembly line working in Modular Consortium [18]. The Modular Consortium is designed as a radical case of outsourcing among an automaker and the small number of direct suppliers, in which: suppliers assume that the pre-assembly of the module is under its responsibility and its subsequent mounting is directly on the production line for the assembly plant, investments in equipments and tools and supply chain the management module; the assembler provides the plant and the final assembly line to execute the coordination of the same and the final test of vehicles [18].

Literature Review is based on Web of Science and Scopus, using descriptors "organizational climate" and "Knowledge Management".

The research instrument use Likert scale ( 5 points). the analysis of results were performed using SPSS version 21.0. 44 blue collar workers were interviewed. The participants were of the male sex with average experience time in 9 years industry with standard deviation 4.49 and the average time in the company of 7.64, standard deviation of 4.19. All participants were immersed in the production process and distributed as follows: assembly $(\mathrm{n}=20)$, brake systems (pipe) $(\mathrm{n}=7)$, manufacturing $(\mathrm{n}=7)$, quality inspectors $(\mathrm{n}=2)$, others $(\mathrm{n}=8)$.

\section{Results and Discussion}

The descriptive analysis of the variables (Table 1) showed that the organization are conspicuous personal interests above the collective and organizational interests (OC1, OC2, OC4), there is a widespread perception in the sample of the company's workers that spent time cajoling theirs superiors (OC3). The majority of the sample preferred not to comment about the OC5 item concerns -Some co-workers try to manipulate the groups which they belong, the most frequent response of the participants was: neutral. Participants agree to point out that within the organization people speak ill of the other to be well valued (OC6).

Respect to Knowledge Management, participants indicated that seek talking to people who help them with their work problems (KM1), or to keep them updated with important information about the organization (KM2). The use of e-mail in this sample is not a tool for the sharing of knowledge, $43.2 \%$ declined to comment on this item (KM3), expressing neutrality and $21.5 \%$ fully disagreed. 
Most also expressed agreement to point out that there is sharing environmental knowledge within the organization (KM4; KM5; KM6; KM7).

The correlation analysis (Table 2) assesses the relationship among the variables related to Organizational Climate and Knowledge Management in the working environment of the organization and relevant results were found and are set out in the Table 2. Significant correlations were shown between the questions studying the Organizational Climate $(\mathrm{p}<0.001)$ and it was similarly as looking to the interior of the questions concerning the Knowledge Management $(0.01<\mathrm{p}<0.05)$, but the level of significance was less strong when compared with the organizational climate.

The KM2 item relating to the use of personal conversation to keep others updated with important information about the organization, showed significant correlation with all the Organizational Climate questions. KM3 and KM7 items of Knowledge Management have not shown correlations with any item on the organizational climate

The participants have the general view of the existence of an unfavorable organizational climate, OC seen as the way in which members of the organization perceive or characterize their working environment [1]. This can be explained by the availability situation experienced in the organization prior to the questionnaire, in which were sent away a group of workers, according [19], the unemployment situation ends up influencing the climate of organizations because of the constant need to meet targets, to be updated, be versatile, teamwork, form great pressure on employees who feel powerless against this context.

Knowledge Management showed a significant relationship to the organizational climate, but the KM doesn't show the weaknesses observed in the OC. One explanation could be that the unemployment situation is recent and may the Organizational Climate has not influenced negatively on the development of knowledge tab. Another explanation may be given by the fact that, despite the employees of the view that colleagues interpose personal interests above the collective and organizational interests, there is still a good communication among them and the prevailing social interaction; as point out by [6]. Positive social interaction results in a higher degree of knowledge sharing and knowledge application, being a mediator in the relationship between organizational structure and Knowledge Management.

However, it was found the correlation between Organizational Climate and Knowledge Management in the plant researched, evidenced by the significant correlations among variables in the analysis, the results are consistent with research in banking [9], educational, hospital [17], among others.

\section{Conclusions}

Through theoretical research and the collection of field data, which were treated with descriptive statistics, we could come to some considerations about the relationship between Organizational Climate and Knowledge Management and the existing process influences among these variables in environment workers 
Table 1. Descriptive data evaluating the responses of participants for each variable.

\begin{tabular}{|c|c|c|c|c|c|c|}
\hline & $\begin{array}{c}\text { Mean }(\mathrm{SD}) \\
\text { Moda }\end{array} \mid$ & $\left|\begin{array}{c}\text { Strongy } \\
\text { Agree } \\
\%\end{array}\right|$ & $\left|\begin{array}{c}\text { Agree } \\
\%\end{array}\right|$ & $\mid \begin{array}{c}\text { Neutral } \\
\%\end{array}$ & $\left|\begin{array}{c}\text { Disagree } \\
\%\end{array}\right|$ & $\begin{array}{c}\text { Fully } \\
\text { Disagree } \\
\%\end{array}$ \\
\hline $\begin{array}{l}\text { There is a lot of self-serving be- } \\
\text { havior going } \\
\text { on here. (OC1) }\end{array}$ & $4.09(1.14) 5 \mid$ & 45.5 & 34.1 & 9.1 & 9.1 & 0 \\
\hline $\begin{array}{l}\text { People do what's best for them, } \\
\text { not what's best } \\
\text { for the organization. (OC2) }\end{array}$ & $3.55(1.19) 4$ & 20.5 & 40.9 & 18.2 & 15.9 & 2.3 \\
\hline $\begin{array}{l}\text { People spend too much time ca- } \\
\text { joling to those } \\
\text { who can help them. (OC3) }\end{array}$ & $|3.73(1.23) 4|$ & 29.5 & 36.4 & 20.5 & 6.8 & 4.5 \\
\hline $\begin{array}{l}\text { People work behind the scenes } \\
\text { to make things } \\
\text { for themselves (OC4) }\end{array}$ & $|3.48(1.17) 4|$ & 18.2 & 36.4 & 29.5 & 9.1 & 4.5 \\
\hline $\begin{array}{l}\text { Many employees are trying to } \\
\text { maneuver their } \\
\text { way into the in group. (OC5) }\end{array}$ & $|3.11(1.15) 3|$ & 13.6 & 20.5 & 36.4 & 25.0 & 2.3 \\
\hline $\begin{array}{l}\text { People speak ill of the other to } \\
\text { be well } \\
\text { valued.(OC6) }\end{array}$ & $|3.68(1.12) 4|$ & 22.7 & 40.9 & 25.0 & 6.8 & 2.3 \\
\hline $\begin{array}{l}\text { I talk to the others seeking help } \\
\text { them with their } \\
\text { work problems (KM1) }\end{array}$ & $|3.30(1.19) 4|$ & 13.6 & 34.1 & 31.8 & 11.4 & 6.8 \\
\hline $\begin{array}{l}\text { I use personal conversation to } \\
\text { keep others } \\
\text { updated with information I have } \\
\text { about the } \\
\text { organization (KM2) }\end{array}$ & $3.52(1.11) 4$ & 15.9 & 43.2 & 25.0 & 11.4 & 2.3 \\
\hline $\begin{array}{l}\text { I use email to communicate and } \\
\text { help colleagues } \\
\text { with problems work (KM3) }\end{array}$ & $|2.59(1.11) 3|$ & 0 & 19.5 & 43.2 & 13.6 & 21.5 \\
\hline $\begin{array}{l}\text { I share my experiences so others } \\
\text { can improve } \\
\text { their own work (KM4) }\end{array}$ & $\mid 4.11(0.92) 4$ & 34.1 & 50.0 & 13.6 & 0 & 0 \\
\hline $\begin{array}{l}\text { My co-workers share their } \\
\text { knowledge and } \\
\text { experiences while working } \\
\text { (KM5) }\end{array}$ & $3.64(1.04) 4$ & 15.9 & 50.0 & 20.5 & 11.4 & 0 \\
\hline $\begin{array}{l}\text { Most people in my organization } \\
\text { are willing to } \\
\text { share what they know (KM6) }\end{array}$ & $|3.80(1.15) 4|$ & 25.0 & 47.7 & 18.2 & 4.5 & 0 \\
\hline $\begin{array}{l}\text { My co-workers volunteer shar- } \\
\text { ing their } \\
\text { knowledge and experiences even } \\
\text { without being } \\
\text { asked (KM7). }\end{array}$ & $3.75(1.01) 4$ & 20.5 & 47.7 & 22.7 & 6.8 & 0 \\
\hline
\end{tabular}


Table 2. Analysis of correlations among variables Organizational Climate and Knowledge Management

\begin{tabular}{|c|c|c|c|c|c|c|c|c|c|c|c|c|c|}
\hline & $\mathrm{OC}$ & $1 \mathrm{OC}$ & $2 \mathrm{OC}$ & $3 \mathrm{OC}$ & OC5 & OC6 & KM1 & KM2 & KM3 & KM4 & KM5 & KM6 & KM7 \\
\hline \multirow{2}{*}{$\mathrm{OC} 1 \frac{\mathrm{r}}{\mathrm{P}}$} & \multirow{2}{*}{-} & $0.72^{*}$ & $* 0.84^{*}$ & * $0.70^{*}$ & $0.60^{*}$ & $0.76^{*}$ & 0.13 & $0.46^{*}$ & 0.09 & $0.43^{*}$ & 0.21 & 0.26 & 0.20 \\
\hline & & 0.00 & 0.00 & 0.00 & 0.00 & 0.00 & 0.45 & 0.00 & 0.58 & 0.003 & 0.18 & 0.09 & 0.19 \\
\hline \multirow{2}{*}{$\mathrm{OC} 2 \frac{1}{p}$} & r 0.72 & & $0.74^{*}$ & * $0.71^{*}$ & $0.64^{*}$ & $0.73^{*}$ & 0.23 & $0.31^{*}$ & 0.03 & $0.41^{*}$ & 0.11 & 0.17 & 0.15 \\
\hline & p 0.00 & & 0.00 & 0.00 & 0.00 & 0.00 & 0.07 & 0.04 & 0.84 & 0.01 & 0.49 & 0.28 & 0.32 \\
\hline \multirow{2}{*}{ OC3 $\frac{r}{P}$} & r 0.84 & * $0.74^{*}$ & & $0.77^{*}$ & $0.68^{*}$ & $0.77^{*}$ & 0.25 & $0.42^{*}$ & 0.02 & $0.42 *$ & 0.23 & 0.17 & 0.19 \\
\hline & $\mathbf{P} \quad 0.00$ & 0.00 & 1 & 0.00 & 0.00 & 0.00 & 0.11 & 0.01 & 0.90 & 0.01 & 0.13 & 0.26 & 0.23 \\
\hline \multirow{2}{*}{$\mathrm{OC} 4 \frac{\mathrm{r}}{\mathrm{p}}$} & r 0.70 & ${ }^{*} 0.71^{*}$ & ${ }^{*} 0.77^{*}$ & & $0.74^{*}$ & $0.76^{*}$ & $0.33^{*}$ & $0.56^{*}$ & 0.12 & $0.40^{*}$ & 0.19 & 0.14 & 0.10 \\
\hline & p 0.00 & 0.00 & 0.00 & 1 & 0.00 & 0.00 & 0.03 & 0.00 & 0.44 & 0.01 & 0.23 & 0.36 & 0.51 \\
\hline \multirow{2}{*}{ OC5 } & r 0.60 & * $0.64^{*}$ & ${ }^{*} 0.68^{*}$ & $0.7^{*}$ & \multirow{2}{*}{1} & $0.72^{*}$ & $0.32^{*}$ & $0.57^{*}$ & 0.07 & $0.45^{*}$ & 0.15 & 0.27 & 0.23 \\
\hline & $\begin{array}{ll}\mathbf{P} & 0.00\end{array}$ & 0.00 & 0.00 & 0.00 & & 0.00 & 0.04 & 0.00 & 0.63 & 0.00 & 0.32 & 0.08 & 0.14 \\
\hline \multirow{2}{*}{$\mathrm{OC} 6$} & r 0.76 & $* 072 *$ & $k \cap 77 *$ & $0.76^{*}$ & $0.72^{*}$ & \multirow{2}{*}{1} & 0.28 & $0.53^{*}$ & 0.04 & $0.51^{*}$ & $0.34^{*}$ & $0.36^{*}$ & 0.24 \\
\hline & $\begin{array}{ll}\mathbf{P} & 0.00\end{array}$ & 0.00 & 0.00 & 0.00 & 0.00 & & 0.06 & 0.00 & 0.78 & 0.00 & 0.02 & 0.02 & 0.12 \\
\hline \multirow{2}{*}{$\mathrm{KM1}_{\mathrm{P}}^{\mathrm{r}}$} & $\begin{array}{ll}\text { r } & 0.12 \\
\end{array}$ & 0.28 & 0.25 & $0.33^{*}$ & $0.32^{*}$ & 0.28 & \multirow{2}{*}{1} & $0.65^{*}$ & $0.45^{*}$ & $0.44^{*}$ & $0.62^{*}$ & $0.52^{*}$ & $0.45^{*}$ \\
\hline & $\begin{array}{ll}\mathbf{P} & 0.45\end{array}$ & 0.07 & 0.11 & 0.03 & 0.04 & 0.06 & & 0.00 & 0.002 & 0.003 & 0.00 & 0.00 & 0.002 \\
\hline \multirow{2}{*}{$\mathrm{KM} 2{ }_{\mathrm{P}}^{\mathrm{r}}$} & r $0.46^{\circ}$ & * $0.31^{*}$ & ${ }^{*} 0.42^{*}$ & $0.56^{*}$ & $0.57^{*}$ & $0.53^{*}$ & $0.65^{*}$ & \multirow{2}{*}{1} & $0.37^{*}$ & $0.58^{*}$ & $0.51^{*}$ & $0.52^{*}$ & $0.41^{*}$ \\
\hline & $\mathbf{P} 0.00$ & 0.04 & 0.01 & 0.00 & 0.00 & 0.00 & 0.00 & & 0.01 & 0.00 & 0.00 & 0.00 & 0.01 \\
\hline \multirow{2}{*}{$\mathrm{KM}^{\mathrm{r}}{ }_{\mathrm{P}}^{\mathrm{r}}$} & $\begin{array}{ll}\mathbf{r} & 0.09\end{array}$ & 0.03 & 0.02 & 0.12 & 0.07 & 0.04 & $0.46^{*}$ & $0.37^{*}$ & \multirow{2}{*}{1} & 0.02 & 0.25 & 0.15 & 0.09 \\
\hline & $\mathbf{P} \quad 0.58$ & 0.84 & 0.90 & 0.44 & 0.63 & 0.78 & 0.002 & 0.01 & & 0.88 & 0.10 & 0.33 & 0.55 \\
\hline \multirow{2}{*}{$\mathrm{KM}^{4}{ }_{\mathrm{P}}^{\mathrm{r}}$} & r $0.43^{\prime}$ & ${ }^{*} 0.41^{*}$ & ${ }^{*} 0.42^{*}$ & $0.40^{*}$ & $0.45^{*}$ & $0.51^{*}$ & $0.44^{*}$ & $0.58^{*}$ & 0.02 & \multirow{2}{*}{1} & $0.56^{*}$ & $0.53^{*}$ & $0.65^{*}$ \\
\hline & $\begin{array}{ll}\mathbf{P} & 0.00\end{array}$ & 0.01 & 0.01 & 0.01 & 0.00 & 0.00 & 0.003 & 0.00 & 0.88 & & 0.00 & 0.00 & 0.00 \\
\hline \multirow{2}{*}{$\mathrm{KM} 5_{\mathrm{P}}^{\mathrm{r}}$} & $\begin{array}{ll}\mathbf{r} & 0.21 \\
\end{array}$ & 0.11 & 0.23 & 0.19 & 0.15 & $0.34^{*}$ & $0.62^{*}$ & $0.51^{*}$ & 0.25 & $0.56^{*}$ & \multirow{2}{*}{1} & $0.56^{*}$ & $0.73^{*}$ \\
\hline & $\mathbf{P} 0.18$ & 0.49 & 0.13 & 0.23 & 0.32 & 0.02 & 0.00 & 0.00 & 0.10 & 0.00 & & 0.00 & 0.00 \\
\hline \multirow{2}{*}{ KM6 } & r $\quad 0.26$ & 0.17 & 0.17 & 0.14 & 0.27 & $0.36^{*}$ & $0.52^{*}$ & $0.52^{*}$ & 0.15 & $0.53^{*}$ & $0.56^{*}$ & \multirow{2}{*}{1} & $0.59 *$ \\
\hline & $\begin{array}{ll}\mathbf{P} & 0.09\end{array}$ & 0.28 & 0.26 & 0.36 & 0.08 & 0.02 & 0.00 & 0.00 & 0.33 & 0.00 & 0.00 & & 0.00 \\
\hline \multirow{2}{*}{ KM7 } & $\begin{array}{ll}\mathbf{r} & 0.20 \\
\end{array}$ & 0.15 & 0.19 & 0.10 & 0.23 & 0.24 & $0.45^{*}$ & $0.41^{*}$ & 0.09 & $0.65^{*}$ & $0.73^{*}$ & $0.59^{*}$ & \multirow{2}{*}{1} \\
\hline & $\begin{array}{ll}\mathbf{P} & 0.19\end{array}$ & 0.32 & 0.23 & 0.51 & 0.14 & 0.12 & 0.002 & 0.01 & 0.55 & 0.00 & 0.00 & 0.00 & \\
\hline
\end{tabular}

Legend: r: correlation coefficient of Pearson, p: significance.

* The correlation is significant at the 0.05 significance level. 
in the researched automotive industry. The results show a relationship between Organizational Climate and Knowledge Management in the automotive sector, evidenced by the significant correlations between the variables analyzed. The unemployment situation can negatively influence the climate of organizations. Participants agree to point that in the organization: personal interests are above the collective and organizational interests and people speak ill of the other to be well valued. Respect to Knowledge Management, participants indicated that seek talking to people and help them with their work problems or keep them updated with important information about the organization. The above suggests that positive social interaction can preserve knowledge sharing, even when there are deficiencies in the organizational climate. Future studies can compare the results of this study with another sample in the same environment in the stable employment situation. Other research may replicate this study with a larger number of participants.

\section{References}

1. Bamel, U.K., Rangnekar, S., Stokes, P., Rastogi, R.: Organizational Climate and Managerial Effectiveness: An Indian Perspective. International Journal of Organizational Analysis 21(2), 198-218 (2013)

2. Janz, B.D., Colquitt, J.A., Noe, R.A.: Knowledge Worker Team Effectiveness: The Role of Autonomy, Interdependence, Team Development, and Contextual Support Variables. Personnel Psychology 50(4), 877-904 (1997)

3. Jaw, B.S., Liu, W.: Promoting Organizational Learning and Self-renewal in Taiwanese Companies: The Role of HRM. Human Resource Management 42(3), 223241 (2003)

4. Chen, C.J., Lin, B.W.: The Effects of Environment, Knowledge Attribute, Organizational Climate, and Firm Characteristics on Knowledge Sourcing Decisions. R and D Management 34(2), 137-146 (2004)

5. Chen, C., Huang, J., Hsiao, Y.: Knowledge Management and Innovativeness: The Role of Organizational Climate and Structure. International Journal of Manpower 31(8), 848-870 (2010)

6. Chen, C.J., Huang, J.W.: How Organizational Climate and Structure Affect Knowledge Management-The Social Interaction Perspective. International Journal of Information Management 27(2), 104-118 (2007)

7. Lin, H., Lee, G.: Effects of Socio-technical Factors on Organizational Intention to Encourage Knowledge Sharing. Management Decision 44(1), 74-88 (2006)

8. Chen, S.S., Chuang, Y.W., Chen, P.Y.: Behavioral Intention Formation in Knowledge Sharing: Examining the Roles of KMS Quality, KMS Self-efficacy, and Organizational Climate. Knowledge-Based Systems 31, 106-118 (2012)

9. Chatzoglou, P.D., Vraimaki, E.: Knowledge-sharing behaviour of bank employees in Greece. Business Process Management Journal 15(2), 245-266 (2009)

10. Llopis, O., Foss, N.J.: Understanding The Climate: Knowledge Sharing Relation: The Moderating Roles of Intrinsic Motivation and Job Autonomy. European Management Journal 34(2), 135-144 (2016)

11. Radaelli, G., Mura, M., Spiller, N., Lettieri, E.: Intellectual Capital and Knowledge Sharing: The Mediating Role of Organisational Knowledge-sharing Climate. Knowledge Management Research and Practice 9(5), 342-352 (2011) 
12. Nonaka, I., Takeuchi, H.: Criação de Conhecimento na Empresa: Como as Empresas Japonesas Geram a Dinâmica da novação. Campus, Rio de Janeiro (1997)

13. Muniz, J., Trzesniak, P., Batista Jr, E.: Um Enunciado Definitivo para o Conceito de Gestão do Conhecimento: Necessidade para o Avanço da Ciência e para a Aplicação Eficaz. Tópicos Emergentes e Desafios Metodológicos em Engenharia de Produção: Casos, Experiências e Proposições 2 (2009)

14. Agarwal, N.K., Islam, M.A.: Knowledge Retention and Transfer: How Libraries Manage Employees Leaving and Joining. VINE 45(2), 150-171 (2015)

15. Massingham, P.: An Evaluation of Knowledge Management Tools: Part 1 - Managing Knowledge Resources. Journal of Knowledge Management 18(6), 1075-1100 (2014)

16. Merrifield, D.B.: Changing Nature of Competitive Advantage. ResearchTechnology Management 43(1), 41-45 (2000)

17. Rees, G.H.: Lean Thinking in New Zealand Emergency Departments. Tesis Doctoral, University of Otago, New Zealand (2011)

18. Pires, S.R.I.: Gestão da Cadeia de Suprimentos e o Modelo de Consórcio Modular. Revista de Administração da Universidade de São Paulo 33(3) (1998)

19. Zamberlan, C.O., Sonaglio, C.M., Ghiliardi, W.J., Dias, E.P.: Influência do Desemprego no Clima Organizacional: Um Estudo de Caso nas Concessionárias de Automóveis de Santa Maria-RS. Jovens pesquisadores-mackenzie 9(1) (2012) 